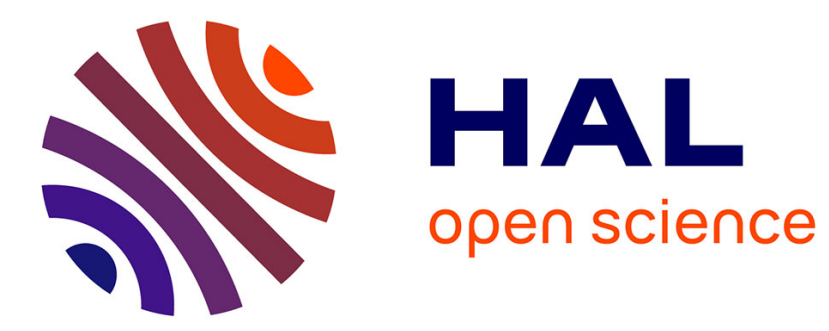

\title{
STUDYING THE FRACTURE OF TROPICAL WOOD SPECIES WITH THE GRID METHOD
}

B Odounga, R Moutou Pitti, Evelyne Toussaint, M Grédiac

\section{To cite this version:}

B Odounga, R Moutou Pitti, Evelyne Toussaint, M Grédiac. STUDYING THE FRACTURE OF TROPICAL WOOD SPECIES WITH THE GRID METHOD. SEM (Society for Experimental Mechanics) Annual Conference, Jun 2017, Indianapolis, United States. hal-01657721

\section{HAL Id: hal-01657721 \\ https://hal.uca.fr/hal-01657721}

Submitted on 7 Dec 2017

HAL is a multi-disciplinary open access archive for the deposit and dissemination of scientific research documents, whether they are published or not. The documents may come from teaching and research institutions in France or abroad, or from public or private research centers.
L'archive ouverte pluridisciplinaire HAL, est destinée au dépôt et à la diffusion de documents scientifiques de niveau recherche, publiés ou non, émanant des établissements d'enseignement et de recherche français ou étrangers, des laboratoires publics ou privés. 


\title{
STUDYING THE FRACTURE OF TROPICAL WOOD SPECIES WITH THE GRID METHOD
}

\author{
B. Odounga ${ }^{1,2}$, R. Moutou Pitti ${ }^{2,3}$, E. Toussaint ${ }^{2}$, M. Grédiac ${ }^{2}$ \\ ${ }^{1}$ Université des Sciences et techniques de Masuku, Ecole Polytechnique de Masuku, BP 901, \\ FRANCEVILLE, Gabon \\ ${ }^{2}$ Université Clermont Auvergne, CNRS, Institut Pascal, F-63000, Clermont-Ferrand, France \\ ${ }^{3}$ CENAREST, IRT, 14070, Libreville, Gabon \\ E-mail: rostand.moutou_pitti@uca.fr
}

Keywords: Crack growth, fracture mechanics, grid method, tropical wood species, compliance method

\section{EXTENDED ABSTRACT}

The present study consists in studying the initiation and propagation of cracks at room temperature of three tropical species: Okume (Aucoumea Klaineana), Iroko (Pterocarpus Soyauxii) and Padouk (Malicia Excelsa). A short review of the literature shows that only few studies dealing with the fracture mechanics properties of this type of wood species are available. Similar studies are however routinely performed on temperate wood species such as Beech and Douglas, using mixed-mode crack growth (MMCG) specimens for instance [1, 2]. In this paper, tropical wood specimens are studied using the grid method [3] and such MMCG specimens, but made of the three aforementioned tropical species.

This paper describes the wood specimens, which are subjected to an opening mode, the experimental device and the background of the grid technique used for tracking the location of the crack tip during the test. The origin and characteristics of the tropical wood species studied here are also given. The experimental results are given and compared in terms of force-displacement curves, but also in terms of energy release rate - crack length curves.

Typical MMCG specimens made of each of the three different species are shown in Figure 1. The main difference between the three species is their density: Okume (density $=0.44)$ is less dense than Iroko (density $=0.64)$ and Padouk (density $=0.79)$. For all the specimens, the initial crack length is the same: $\mathrm{a}=20 \mathrm{~mm}$. It is located at mid-height and oriented along the fiber direction, which is horizontal here. The initial crack is completed by a notch (length: $2 \mathrm{~mm}$ ) made with a cutter in order to initiate correctly crack propagation. A grid, with a regular pitch of 200 microns, was transferred on one face of the specimens, see Figure 1 (d). The technique presented in [4] is used for this purpose.
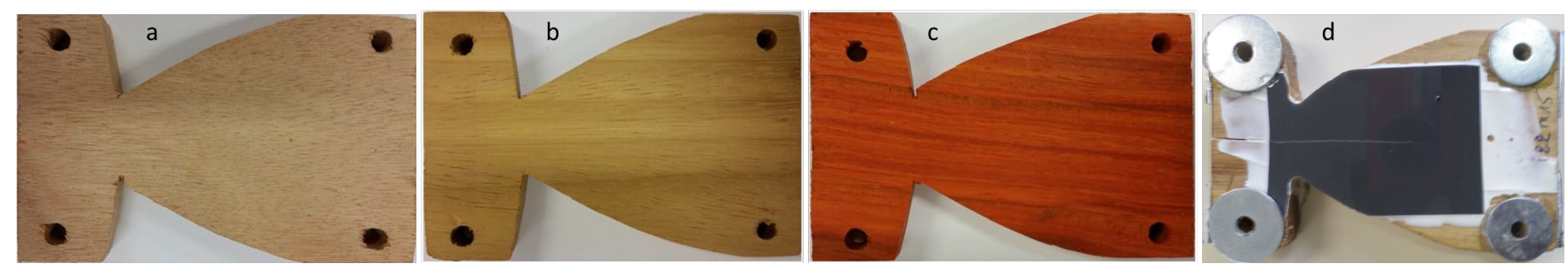

Figure 1. Wooden specimens: Okume (a), Iroko (b), Padouk (c) and the specimen Iroko equipped grid (d).

The experimental device is shown in Figure 2. A $200 \mathrm{kN} \mathrm{Zwick} \mathrm{/} \mathrm{Roel} \mathrm{testing} \mathrm{machine} \mathrm{was} \mathrm{used} \mathrm{for} \mathrm{the} \mathrm{tests.} \mathrm{A} \mathrm{camera} \mathrm{was}$ fixed on a tripod at a distance of $67.5 \mathrm{~cm}$ from the specimens in order to take images of the grid during the tests. 


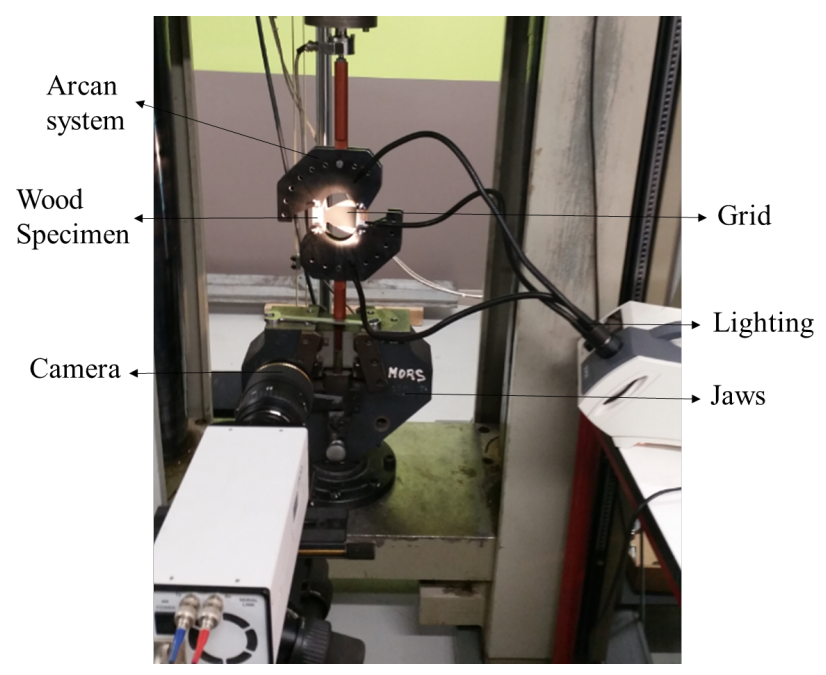

Figure 2: Experimental device

A small sized steel Arcan fixture was used to load the specimens. The lower part was fixed and the upper part was subjected to an imposed displacement. The testing machine was equipped with a force transducer in order to obtain the force-displacement curves, the displacement being obtained with the full-field measurements. The cross-head speed was $0.005 \mathrm{~mm} / \mathrm{s}$, and the acquisition rate of the camera was 1.35 frames/second. The specimens were illuminated by three flexible optical arms powered by a cold light source KL 2500 LCD. A SIGMA $105 \mathrm{~mm}$ objective was mounted on the camera. To minimize image noise, each image was averaged over 8 frames.

Two specimens per specie were tested. Figure 3 (a) shows the force-displacement curves obtained for the three species, thus for the 6 tested specimens. Although the curves are somewhat scattered, a clear trend appears. Indeed, there is a link between force at failure and density. For Okume the mean force at failure is nearly $F_{R(\text { okume })}=600 \mathrm{~N}$, causing an opening of the crack $d_{\text {okume }}=0.035 \mathrm{~mm}$. For Iroko this mean value is a slightly greater since $F_{R(\text { Iroko })}=1000 \mathrm{~N}$, with $d_{\text {Iroko }}=$ $0.034 \mathrm{~mm}$. For Padouk, we have $F_{R(\text { Padouk })}=1400 \mathrm{~N}$ and $d_{\text {Padouk }}=0.031 \mathrm{~mm}$.

The results obtained during these tests were then used in order to obtain the critical energy release rate G, which writes as follows:

$$
G_{c}=\frac{F_{C}^{2}}{2 \cdot b} \cdot\left(\frac{\Delta C}{\Delta a}\right)_{d}
$$

where $F_{C}$ is the so-called critical force corresponding to an increase $d a$ of the crack length $a, b$ is the thickness of the specimen. $C=U / F$ is the compliance, where $U$ is the crack opening, and $\Delta C$ is the increase in compliance between after and before the crack length has increased by a quantity denoted $\Delta a$.
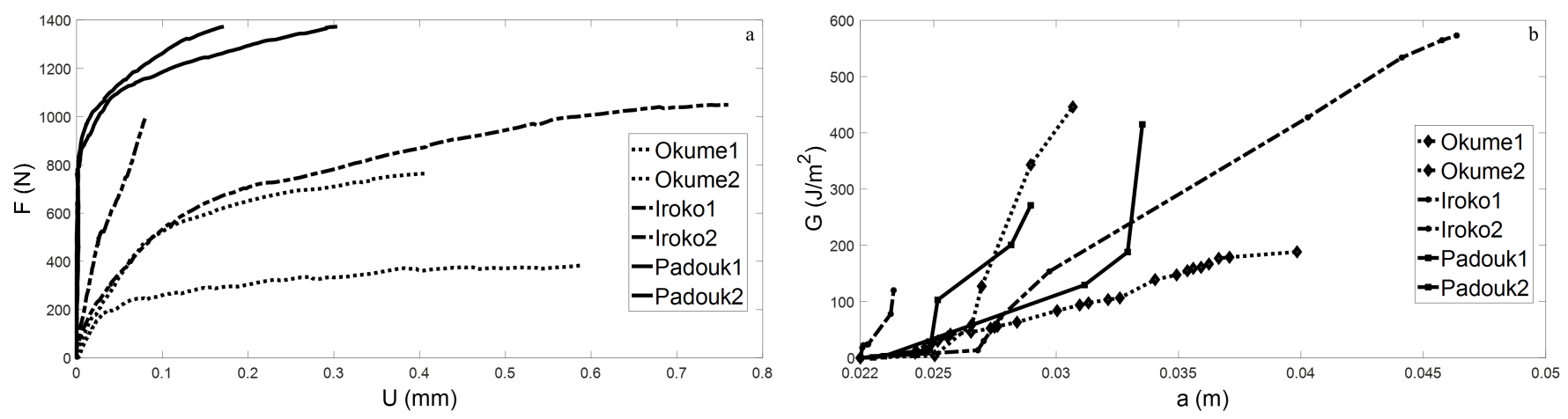

Figure 3. Force-crack opening curves (a), evolution of $G$ vs. crack length $a$ (b) for the three woods species. 
Figure 3 (a) shows the value of $\mathrm{F}$ as a function of the crack opening $\mathrm{U}$ obtained by the grid method. Figure 3 (b) shows the value of $G$ as a function of the length of crack a. The first values of $G$, which induce the onset of crack propagation in the material, confirm the impact of density on the fracture for the three tropical species. Much more energy is needed to initiate a crack propagation in Iroko than in Okume and still more in Padouk. Indeed, the average of $\mathrm{G}$ of the two test pieces of each tested of the species showed that the initiation of a crack propagation in Okume requires an energy equal to $G=6 \mathrm{~J} / \mathrm{m}^{2}$. For Iroko, this value is $G=14 \mathrm{~J} / \mathrm{m}^{2}$ and for Padouk, $G=15 \mathrm{~J} / \mathrm{m}^{2}$.

When we consider the mean of the extreme $G$ values, let us say to failure, we observe that the difference between the three species is no longer significant. Therefore the effect of the density is no longer observable. They revolve around $G=350 \mathrm{~J} / \mathrm{m}^{2}$.

Tests were carried out on three tropical species: Okume, Iroko and Padouk. The grid method was applied in order to track the crack tip during the test performed in opening mode. The results showed the influence of the density on the identified fracture parameters, since the denser the material, the greater the force at failure. These results also highlight the influence of the density on the energy which is necessary to initiate the propagation of the crack in these wood species. Indeed, we observed that the first value initiating the propagation of the crack increases with the density.

\section{REFERENCES}

[1] Moutou Pitti R., Dubois, F., Petit, C., Sauvat, N. Mixed mode fracture separation in viscoelastic orthotropic media: numerical and analytical approach by the Mtv-integral. International Journal of Fracture, 145: 181-193, 2007.

[2] Moutou Pitti R., Dubois F., Pop O.. On a specimen providing stable mixed mode crack growth in wooden material. Original Research Article. Comptes Rendus Mécanique, 336(9): 744-749, 2008.

[3] Grédiac M, Sur F., \& Blaysat B.. The Grid Method for In-plane Displacement and Strain Measurement: A Review and Analysis. Strain, 52(3): 205-243, 2016.

[4] Piro J.L, Grédiac M., Producing and transferring low-spatial-frequency grids for measuring displacement fields with moiré and grid methods, Experimental Techniques, 28(4): 23-26, 2004 